\title{
Effect of tomato (Solanum lycopersicum L.) protein on carcass and meat quality of kampong chicken
}

\author{
J. R. Leke*, J. S. Mandey, F. Ratulangi and M. Najoan \\ Faculty of Animal Husbandry, Sam Ratulangi University, \\ Jl. Kampus Selatan, Manado 95115 - Indonesia \\ *CorrespondingE-mail: rinileke@yahoo.com
}

Received September 05, 2017; Accepted December 21, 2017

\begin{abstract}
ABSTRAK
Penelitian bertujuan untuk mengetahui kualitas karkas dan daging ayam kampung yang mengkonsumsi tepung tomat dalam ransum. Penelitian ini dilakukan menggunakan 200 ekor ayam kampung umur 10 hari. Rancangan yang digunakan dalam penelitian ini adalah rancangan acak lengkap (RAL) yang terdiri dari 5 perlakuan dan 4 ulangan dan tiap perlakuan terdiri dari 10 ekor ayam kampung Perlakuan yang diberikan adalah $0,3,6,9$ dan $12 \%$ tepung tomat yang disubstitusi pada ransum basal. Ransum basal terdiri dari $42 \%$ jagung, dedak halus $9 \%$, tepung ikan $10 \%$, minyak ikan 5\%, bungkil kedelai $9 \%$ dan ransum komersial $25 \%$. Perlakuan adalah $\mathrm{PO}=100 \%$ ransum basal $(\mathrm{RB})+0 \%$ tepung tomat (TT); P1 $=97 \% \mathrm{RB}+3 \%$ TT; $\mathrm{P} 2=94 \% \mathrm{RB}+6 \% \mathrm{TT} ; \mathrm{P} 3=91 \% \mathrm{RB}+9 \% \mathrm{TT} ; \mathrm{P} 4=88 \% \mathrm{RB}+$ $12 \%$ TT. Komposisi kimia tepung tomat adalah: 20,73\% protein kasar, 1,53 \% lemak, 30,94\% serat kasar, 0,98\% Ca, 1,20\% P dan $2.416 \mathrm{kkal} / \mathrm{kg}$ Gross Energy (GE). Hasil penelitian menunjukkan bahwa pemberian ransum yang mengandung tepung tomat sampai $12 \%$ meningkatkan berat potong, karkas, dada, sayap, kaki dan paha, dan menurunkan lemak abdominal dan kolesterol darah, tetapi tidak berpengaruh pada liver, hati dan gizzard. Kandungan air dan protein kasar daging nyata meningkat, lemak daging dan kolesterol daging nyata menurun. Disimpulkan bahwa tepung tomat dapat digunakan dalam pakan ayam kampung sampai $12 \%$ karena tidak memberikan pengaruh pada kualitas karkas dan daging ayam kampung.
\end{abstract}

Kata Kunci: ayam kampung, kualitas daging, kualitas karkas, protein, tomat

\begin{abstract}
The purpose of this research was to examine the carcass quality and meat quality of native chicken fed dried tomato meal in diet. The study was conducted by using 200 heads of native chickens 10 days. The birds were divided into five experimental diets and each was divided into four replicate groups of ten birds per replicate. The based diet was formulated to contain $42 \%$ corn, rice bran $9 \%$, fish meal $10 \%$, fish oil $5 \%$, soybean meal $9 \%$ and commercial diets $25 \%$. Tomato meal was included in five experimental diets at levels of $0,3,6,9,12 \%$ to substitute based diets. The treatments were $\mathrm{PO}=100 \%$ based diet $(\mathrm{BD})+0 \%$ tomato meal $(\mathrm{TM}) ; \mathrm{P} 1=97 \% \mathrm{BD}+3 \% \mathrm{TM} ; \mathrm{P} 2=94 \% \mathrm{BD}+6 \% \mathrm{TM} ; \mathrm{P} 3=91 \%$ $\mathrm{BD}+9 \% \mathrm{TM} ; \mathrm{P} 4=88 \% \mathrm{BD}+12 \% \mathrm{TM}$. Chemical composition of tomato meal was: $20.73 \%$ crude protein, $1.53 \%$ fat, $30.94 \%$ crude fiber, $0.98 \% \mathrm{Ca}, 1.20 \% \mathrm{P}$ and $2,416 \mathrm{kcal} / \mathrm{kg}$ of Gross Energy (GE). Results showedthat feeding tomato meal at an inclusion rate of $12 \%$ increased slaughter weight, carcass, breast meat, wings, drumstick and thigh, and decreased abdominal fat and blood cholesterol. Moreover, there were no significant difference in giblet (liver, heart and gizzard) between treatments. Meat water and meat crude protein were significantly increased. Meat crude fat and meat cholesterol were significantly decreased. In conclusion, tomato meal can be used as an alternative feedstuff in kampong
\end{abstract}


chicken diets at inclusion levels up to $12 \%$ without negative effects on carcass quality and meat quality. Keywords :carcass quality, meat quality, kampong chicken, protein, tomato

\section{INTRODUCTION}

Kampong chicken have been raised by most of the rural community population of Indonesia and they represent an important source of meat and eggs. Kampong chickens are still not able to provide consumption on a daily basis because of their low production. Kampong chickens contribute a lot to household nutrition and income in rural areas of tropics (Norris et al., 2007). However, improving nutrition for increasing egg and meat production in kampong chickens in Indonesia is critical. Productivity of kampong chicken breeds may be doubled with improved diets and management conditions (Chowdhury et al., 2006). But the kampong chickens have not attained their full production potencial due to exposure to risks that influence against the survival and productivity under extensive management conditions (Faruque et al., 2013). One on the top issues of kampong chickens is a tasty meat flavor. The people are more prefer to consume this type of chickens than that of commercially broiler chickens. Therefore, the demand for kampong chickens is always increasing year to year, while only a small portion of it has been met (Bamualim et al., 1994).

The nutrional value of tomato can provide the poultry industry as an alternative feedstuff. The tomato seed is rich in protein lysine (approximately $13 \%$ more lysine than soya protein) and can supply feed that is deficient in lysine (Latlief and Knorr., 1983). The chemical analysis of tomato meal showed rich in protein $(20.73 \%)$ and contains high fibre content $(30.94 \%)$. The high nutrient content of tomato meal makes it a potential feed resource for livestock animals. The crude protein content of tomato meal was higher than the value of crude protein of tomato waste meal. Tomato pomace could be used in broiler chicken diets up to level $20 \%$. Using of dried tomato pomace (only separated tomato seeds) in broiler chicken diets caused an extended shelf life for broiler meats, because of alpha-, beta-, gamma- and delta tocopherols in tomato pomace cause an antioxidant effect (Squires et al., 1992).

Tomato pulp is a good source of protein, vitamins and minerals but may be limited in energy due to the high fiber content (Mansori et al.,2008) substitution of tomato pulp instead of other dietary ingredients shows comparable performance parameters in laying hen (Jafari et al., 2006). The mentioned study showed that dried tomato pomace including rich food sources, has caused the poultry health and freshness and better feed digestion, as a result, it can increase the absorption of nutrients (Asadollahi et al., 2014).

Tomato also contains a variety of phytochemical, including carotenoids and polyphenols (Thompson et al., 2000; Campbell et al., 2014). Tomatoes and tomato products are the major dietary source of lycopene, folate, vitamin $\mathrm{C}$, vitamin A, phenolics, and flavonoids as potential bioactive compounds (Sahin et al., 2006). Recent studies have suggested a protective role for lycopene, an antioxidant carotenoid, in the prevention of environmental stress and lead to better performance for birds (Donkoh., 1989; Sahin, et al., 2008).

The red pigment contained in tomatoes is called lycopene. This compound appears to act as an antioxidant, neutralizing free radicals that can damage cells inthe body (Bhowmik et al., 2012). Along with carotenoids, other antioxidant compounds present in tomato, including ascorbic acid, tocopherols and phenols play a determinant role in disease prevention (Karakaya et al., 2001). The dried tomato pomace is mainly consisted of tomato's skin, seed and its hard texture. This byproduct, after being dried contains up to $22.1 \%$ $22.4 \%$ protein, $14.5 \%-15.7 \%$ fat and $20.8 \%$ $30.5 \%$ fiber. It is a good source of A, B1 and B2 vitamins and also essential (and non-essential) amino acids (Fallahi., 1996).

According to Jouzi et al. (2015), dried tomato pulp may be used as ingredient in quails ration up to level of 4-6\% without harming weight gain and feed conversion of birds. Tomato waste has used as feedstuff in broiler diet up to $20 \%$ level without harming weight gain and feed conversion of poultry (Lira et al., 2010).

When formulating the diets, the main emphasis is placed on the crude protein, because protein is the critical constituent of poultry diets, and together with the other main nutrients such as carbohydrates, fat, water, vitamins, and minerals, is essential for life (Cheeke., 2005). Protein serve vital metabolic roles as blood plasma proteins, enzymes, hormones, and antibodies, each of 
which has a specific role in the body (Pond et al., 1995). However, protein is also one of the most expensive ingredients in poultry diets. Therefore, nutritionally and economically, proper protein usage is essential in all feeding systems. On the other hand, during broiler diet formulation, choosing ingredients to maximize nutrient availability, rather than simply meeting energy or amino acid levels, is necessary (Ravindran., 2013).

In poultry feed formulation, after the energy -yielding raw materials, protein supplements constitute the biggest component, and attention has been focused on the protein and energy levels of the feed (Skinner et al., 1992). Vegetable (plant) and animal products are the two most important protein sources in poultry diets. The usefulness of a protein feedstuff for poultry depends up on its ability to supply a sufficient amount of the essential amino acids that the bird requires, as well as the protein digestibility and the level of toxic substances associated with it (Scanes et al., 2004).

In general, vegetable (plant) protein sources are nutritional balanced and poor in certain essential amino acids and this decreases their biological value as they may not furnish the required limiting amino acids needed by birds for egg and meat production (Akhter et al., 2008). Formulation of poultry diets greatly depends on plant protein that can supply the necessary amino acids that are not available in adequate quantities in the cereals (Atteh., 2000). Plant protein is relatively cheaper and readily available than the animal protein source.

The Objectives of this study were to evaluate effect protein of tomato on carcass and meat quality of kampong chickens.

\section{MATERIALS AND METHODS}

\section{Preparation of Tomato Meal}

The tomatoes were washed, cutted, and sundried to constant weight for 3-5 days. Part of tomato then was ground to fine powder using mortar and pestle. After that, mixed with other ingredients to compound the feed.

\section{Birds, Feeding and Management}

Two hundred of kampong chickens (10 days of age) were used for the study and maintained for 105 days. The birds were divided into five experimental diets and each was divided into four replicate groups of ten birds per replicate using completely randomized design. The control diet (based diet) was formulated to contain $42 \%$ corn, rice bran $9 \%$, fish meal $10 \%$, fish oil $5 \%$, soybean meal $9 \%$ and commercial diets $25 \%$. Tomato meal was included in four experimental diets at levels of 3,6, 9 and $12 \%$ to substitute based diet. The treatments were: $\mathrm{RO}=100 \%$ based diet $(\mathrm{BD})+$ $0 \%$ Tomato meal $(\mathrm{TM}) ; \mathrm{R} 1=97 \% \mathrm{BD}+3 \% \mathrm{TM}$; $\mathrm{R} 2=94 \% \mathrm{BD}+6 \% \mathrm{TM}, \mathrm{R} 3=91 \% \mathrm{BD}+9 \%$ $\mathrm{TM}, \mathrm{R} 4=88 \% \mathrm{BD}+12 \% \mathrm{TM}$. Chemical composition of tomato meal was: $20.73 \%$ crude protein, $1.53 \%$ fat, $30.94 \%$ crude fiber, $0.98 \%$ $\mathrm{Ca}, 1.20 \% \mathrm{P}$ and $2,416 \mathrm{Kcal} / \mathrm{Kg}$ of Gross Energy (GE), and chemical composition of the diets are presented in Table 1.

At termination of the experiment, twenty chickens representing weight average of the group were taken carcass characteristics, and chemical composition of breast and thigh muscles were determined.

\section{Chemical Analysis}

Proximate analysis of diet and meat of kampong chickens was determined by the methods of AOAC (1996). Crude protein was determined by multiplying crude nitrogen by 6.25 . Cholesterol was determined by Libermann and Burchad Method (Kenny, 1952)

\section{Statistical Analysis}

Data were analyzed by one-way analysis of variance. Probability values $<0.05$ were taken to indicate statistical significance. The treatments means were compared using Duncan's Multiple Range Test (Steel and Torrie, 1980). The IBM SPSS Statistics 22 software was used for the statistical processing of data.

\section{RESULTS AND DISCUSSION}

The effects of dietary dried tomato meal on the carcass quality and meat quality of kampong chicken are presented Table 2 and Table 3. Results showed that feeding tomato meal at an inclusion rate of $12 \%$ increased slaughter weight, carcass, breast meat, wings, drumstick and thigh, and decreased abdominal fat and blood cholesterol. Moreover, there were no significant difference in giblet (liver, heart and gizzard) between treatments. Meat water and meat crude protein were significantly increased, however, meat crude fat and meat cholesterol were significantly decreased (Table 3).

Leke et al. (2015) in previous study reported 
Table 1. Composition of Experimental of the Diets

\begin{tabular}{lccccc}
\hline \multirow{2}{*}{ Nutrient Composition } & \multicolumn{5}{c}{ Diets (\% of TM) } \\
\cline { 2 - 6 } & $0^{*}$ & $3^{* *}$ & $6^{* *}$ & $9^{* *}$ & $12^{* *}$ \\
\hline Base Diet & 100 & 98 & 96 & 94 & 92 \\
TM & 0 & 2 & 4 & 6 & 8 \\
Crude protein (\%) & 15.71 & 18.87 & 18.64 & 19.09 & 19.77 \\
Fat (\%) & 4.36 & 2.97 & 2.59 & 2.97 & 3.29 \\
Crude Fiber (\%) & 3.56 & 4.16 & 4.45 & 5.58 & 6.26 \\
Ca (\%) & 0.80 & 0.80 & 0.81 & 0.82 & 0.82 \\
P(\%) & 0.86 & 0.87 & 0.88 & 0.85 & 0.90 \\
GE (Kcal/kg) & 3057 & 3037 & 3018 & 2999 & 2980 \\
\hline
\end{tabular}

$\mathrm{TM}=$ Tomato meal

* Laboratory of Science and Technology of Feed, Bogor Agricultural University (2017)

**Laboratory of Nutritional Biochemistry and Fodder, Gadjah Mada University (2017)

Table 2. Carcass and Meat Quality of Kampong Chickens

\begin{tabular}{lcccccc}
\hline \multicolumn{1}{c}{ Variable } & $0 \% \mathrm{TM}$ & \multirow{2}{*}{$3 \% \mathrm{TM}$} & $6 \% \mathrm{TM}$ & $9 \% \mathrm{TM}$ & $12 \% \mathrm{TM}$ & $\begin{array}{c}P \\
\text { Value }\end{array}$ \\
\hline Slaughter Weight (g) & $1230 \pm 15.72^{\mathrm{a}}$ & $1241 \pm 23.37^{\mathrm{a}}$ & $1339 \pm 17.51^{\mathrm{b}}$ & $1330 \pm 20.13^{\mathrm{b}}$ & $1471 \pm 22.75^{\mathrm{c}}$ & .000 \\
Carcass (\%) & $71.2 \pm 0.13^{\mathrm{a}}$ & $72.1 \pm 0.43^{\mathrm{b}}$ & $74.2 \pm 0.53^{\mathrm{c}}$ & $74.5 \pm 0.43^{\mathrm{d}}$ & $74.7 \pm 0.16^{\mathrm{d}}$ & .000 \\
Breast Meat (\%) & $28.59 \pm 0.31^{\mathrm{a}}$ & $29.49 \pm 0.07^{\mathrm{a}}$ & $32.11 \pm 1.82^{\mathrm{b}}$ & $33.88 \pm 0.66^{\mathrm{c}}$ & $34.58 \pm 0.29^{\mathrm{c}}$ & .000 \\
Wings (\%) & $12.15 \pm 0.45^{\mathrm{a}}$ & $12.49 \pm 0.46^{\mathrm{a}}$ & $13.27 \pm 0.54^{\mathrm{b}}$ & $13.36 \pm 0.38^{\mathrm{b}}$ & $14.22 \pm 0.13^{\mathrm{c}}$ & .000 \\
Drumstick +Thigh (\%) & $31.63 \pm 0.21^{\mathrm{a}}$ & $32.08 \pm 0.01^{\mathrm{b}}$ & $32.92 \pm 0.11^{\mathrm{c}}$ & $35.41 \pm 0.47^{\mathrm{d}}$ & $35.45 \pm 0.41^{\mathrm{d}}$ & .000 \\
Abdominal Fat (\%) & $1.88 \pm 0.11^{\mathrm{b}}$ & $1.44 \pm 0.29^{\mathrm{b}}$ & $1.32 \pm 0.17^{\mathrm{a}}$ & $1.39 \pm 0.32^{\mathrm{a}}$ & $1.25 \pm 0.17^{\mathrm{a}}$ & .000 \\
Abdominal Fat (g) & $20.78 \pm 0.69^{\mathrm{c}}$ & $19.52 \pm 0.46^{\mathrm{b}}$ & $19.12 \pm 1.08^{\mathrm{ab}}$ & $18.44 \pm 0.74^{\mathrm{a}}$ & $18.26 \pm 1.51^{\mathrm{a}}$ & .000 \\
Blood Cholest. (mg/dl) $136.62 \pm 0.30^{\mathrm{d}}$ & $133.64 \pm 0.31^{\mathrm{c}}$ & $122.42 \pm 1.32^{\mathrm{a}}$ & $123.90 \pm 0.57^{\mathrm{b}}$ & $122.22 \pm 1.33^{\mathrm{a}}$ & .000 \\
Liver (\%) & $2.80 \pm 0.14$ & $2.74 \pm 0.19$ & $2.42 \pm 0.14$ & $2.50 \pm 0.14$ & $2.38 \pm 0.14$ & .000 \\
Heart (\%) & $0.63 \pm 0.10$ & $0.68 \pm 0.10$ & $0.64 \pm 0.03$ & $0.62 \pm 0.06$ & $0.60 \pm 0.02$ & .528 \\
Gizzard (\%) & $3.09 \pm 0.17$ & $3.14 \pm 0.10$ & $2.91 \pm 0.08$ & $3.11 \pm 0.34$ & $2.80 \pm 0.20$ & .062 \\
\hline
\end{tabular}

$\mathrm{TM}=$ tomato meal

that the whole egg nutrients have similar quality to based diet when chicken fed tomato diet up to $8 \%$, so that could have beneficial nutritional impact for laying hens. Leke et al. (2016) reported effect of dried tomato in diet up to $8 \%$ without negative effects on performance and egg quality.
These suggest that the use of tomato meal in laying hen diets might have positive effects on whole egg quality.

Yitbarek (2013) showed that carcass yield values were higher for a group fed on 5\% dried tomato pomace compared with other treatment 
Table 3. Water, Crude Protein, Crude Fat and Cholesterol of Meat of Kampong Chickens

\begin{tabular}{lcccccc}
\hline \multicolumn{1}{c}{ Variable } & $0 \% \mathrm{TM}$ & $3 \% \mathrm{TM}$ & $6 \% \mathrm{TM}$ & $9 \% \mathrm{TM}$ & $12 \% \mathrm{TM}$ & $p$ Value \\
& & & & & & \\
Water (\%) & $72.58 \pm 0.55^{\mathrm{a}}$ & $73.26 \pm 0.56^{\mathrm{bc}}$ & $72.78 \pm 0.44^{\mathrm{ab}}$ & $73.50 \pm 0.47^{\mathrm{c}}$ & $74.72 \pm 0.16^{\mathrm{d}}$ & .000 \\
Crude Protein (\%) & $20.56 \pm 0.42^{\mathrm{a}}$ & $22.08 \pm 1.30^{\mathrm{b}}$ & $22.34 \pm 0.82^{\mathrm{bc}}$ & $23.26 \pm 0.42^{\mathrm{cd}}$ & $23.60 \pm 0.29^{\mathrm{d}}$ & .000 \\
$\begin{array}{l}\text { Crude Fat (\%) } \\
\text { Meat Cholesterol } \\
(\mathrm{mg} / 100 \mathrm{~g})\end{array}$ & $2.64 \pm 0.20^{\mathrm{d}}$ & $2.28 \pm 0.08^{\mathrm{c}}$ & $2.15 \pm 0.05^{\mathrm{bc}}$ & $2.07 \pm 0.06^{\mathrm{ab}}$ & $1.96 \pm 0.13^{\mathrm{a}}$ & .000 \\
\hline
\end{tabular}

$\mathrm{TM}=$ tomato meal

groups. But statistically there were no significant difference between the groups. Moreover, the obtained result was not similar to that reported by King and Zeidler (2004) who showed that dried tomato pomace up to $15 \%$ in diet does not affect carcass traits of broiler chicks. Sayed and Abdelazeem (2009) reported that dried tomato pomace can be utilized efficiently and safely in the diets of rabbits up to level of $20 \%$ without any adverse effect on the performance and carcass traits. Significantly similar carcass yield and dressing percentage was observed at $20 \%$ of dried tomato pomace inclusion on grower chicks (Yitbarek., 2013). Our results indicated that alterations in feed intake and weight gain in some phases promoted by inclusion of tomato meal. Chemical composition of tomato meal were : $16.73 \%$ crude protein, $1.53 \%$ fat, $30.94 \%$ crude fiber, $0.98 \% \mathrm{Ca}$, $1.20 \% \mathrm{P}$ and $2,416 \mathrm{Kcal} / \mathrm{kg} \mathrm{GE}$ ( Leke et al., 2016)

Squires et al. (1992) reported that tomato pomace could be used in broiler chicken diets up to level of $20 \%$. That using of dried tomato pomace (only separated tomato seeds) in broiler chicken diets were caused an extended shelf life for broiler meats, because of alpha-, beta-, gamma- and delta tocopherols in tomato pomace cause an antioxidant effect.

In the present study, a positive effect of dried tomato meal on cholesterol concentration in the blood of kampong chicken was observed. The obtained results were similar to that reported by Rahmatnejad et al. (2009) who showed that feeding dried tomato pomace at an inclusion rate of $16 \%$ and $24 \%$ to broiler chicks increased the mean values of HDL-cholesterol and decrease in serum cholesterol and LDL-cholesterol, as compared to other dietary treatments. Moundras et al. (1997) said that the serum cholesterol decreasing effect of crude fiber could be due to its ability to enchange faecal excretion of cholesterol and bile acids. Burr et al. (1985) suggested that there is a negative correlation between dietary fiber content and serum cholesterol level. It is possible that for a significant reduction of serum cholesterol, a higher inclusion level of dried tomato pomace in laying hen diets is required. Mahata et al. (2016) reported that the total cholesterol, LDL-cholesteroland HDL-cholesterol of laying-hen's blood serum and fat content of egg yolk was not affected by different levels of boiled tomato waste powder up to $12 \%$ in diets. Even though there were no difference among treatments statistically but numerically it appeared that increasing in the level of boiled tomato waste powder in the diet lowered the total cholesterol and LDL tremendously and increased the HDL.

In contrast, Frederiksen et al. (2007) showed that dietary supplementation with an extract of lycopene rich tomatoes had no effect on cholesterol and triglycerol levels measured in rabbit's plasma. Feeding dried tomato pomace to laying hens had no effect on plasma cholesterol and low-density lipoproteins (Nobakht and Safamehr, 2007).

Results of abdominal fat and giblet in this experiment are not in agreement with those reported of Lira et al. (2010), in which there was no difference between regime with different levels of tomato waste for absolute weight of heart, liver and gizzard neither for yield of gizzard, with means of $13.35 \mathrm{~g} ; 41.83 \mathrm{~g}, 34.87 \mathrm{~g}$ and $1.94 \%$, respectively. However, for yield of heart and liver, there was linear effect, because for each $1 \%$ of tomato waste inclusion, there was an increase of 0.0036 and $0.0133 \%$, respectively. Effect of 
dietary supplemental plant extracts on different organ weights was reported by Akbarian et al. (2013). Relative spleen, pancreas, gizzard, liver, proventriculus, thigh, breast, heart and visceral fat weight were not influenced by the use of plant extract.

The statistics analysis results of moisture, protein, fat, and cholesterol of meat in this research in different levels of dried tomato pomace significantly different and using $12 \%$ of dried tomato pomace showed the best result. Asadollahi et al. (2014) reported that results of protein, fat, moisture and ash of meat in different levels of dried tomato pomace up to $10 \%$ were significantly increased (Asadollahi et al., 2014). Comparing the studied parameters showed that increasing the amount of used dried tomato meal up to $12 \%$ leads to increase both water and protein content, but reduces the fat and meat cholesterol content of the kampong chicken texture which consequently increased overall consumer acceptability. In general, according to the obtained results of each of the five parameters, the treatment which contained $12 \%$ dried tomato meal was determined as the best one and was recommended to be added to the diet of chickens.

Proteins and lipids of muscle tissue are important meat quality parameters. Normally thigh meat fat content in broiler is $90.44 \mathrm{~g} / \mathrm{kg}$ to $107.55 \mathrm{~g} / \mathrm{kg}$ in female and $76.95 \mathrm{~g} / \mathrm{kg}$ to 96.83 $\mathrm{g} / \mathrm{kg}$ in male. They contribute substantially to the nutritional characteristics of meat. Mahata et al. (2014) reported the inclusion of dragon fruit peel in broiler diet up to $15 \%$ lowering fat and cholesterol content in thigh meat. The level of dragon fruit peel 10 and $15 \%$ in diet were as same as effect in lowering fat content, while the highest lowering cholesterol in thigh meat occured when the dragon fruit peel was included reach $15 \%$ in diet. It be predicted, lowering fat and cholesterol in thigh meat due to anthocyanin, lycopen, and $\beta$ carotene from dragon fruit peel inhibited cell cholesterol synthesis by inhibiting HMG-CoA reductase work to synthesize mevalonate as intermediate reaction in cholesterol synthesize in cell.

\section{CONCLUSION}

Based on the present data, it can be concluded that tomato meal can be used as an alternative feedstuff in kampong chicken 105 days of age diets at inclusion levels up to $12 \%$ without negative effects on carcass quality and meat quality.

\section{REFERENCES}

Akbarian, A., A. Golian, H. Kermanshahi, R. Farhoosh, A.R. Raji,S. De Smetand J. Michiels. 2013. Growth performance and gut health parameters of finishing broilers supplemented with plant extracts and exposed to daily increased temperature. Spanish J. Agric. Res. 11(1):109-119.

Akhter, S., M. Khan, M. Anjum, S. Ahmed, M. Rizwan and M. Ijaz. 2008. Investigation on the availability of amino acids from different animal protein sources in golden cockerels. J. Anim. Plant Sci.18:53-54.

Asadollahi, S., N. Karimi and A. Mansuri. 2014. Using of dried tomato pomace in broiler's diet and it's effect on chemical components of obtained meat. International Conference on Chemical, Agricultural, and Biological Sciences (ICCABS) Oct. 9-10, 2014, Antalya (Turkey). P. 28-32.

Association of Official of Analytical Chemist (AOAC). 1996. Methods of Analysis. $13^{\text {th }}$ Washington D.C., USA.

Atteh, J.O. 2000. Principles and practices of Feed Manufacturing: Publishers: Adlek Printers, Ilorin, Kwara State.

Bamualim, U., Kedang, A. and S. Ratnawaty. 1994. Rearing manajement model on native chicken in Indonesia due to small farmer income in dry lands. National annual meeting on implementation and communication research findings. P. 256260.

Bhowmik, D., K.P. Sampath Kumar, S. Paswan and S. Srivastava. 2012. Tomato-A natural medicine and its health benefits. J. Pharmacognosy and Phytochemistry.1 (1): 33-43.

Burr, M.L., P.M. Sweetnam, M.E. Barasi and C.J. Bates.1985. Correlation between dietary content and serum cholesterol in laying hens. Nutr. Res. 5:465-465.

Campbell, J.K., K. Canene-Adams, B.L.L. Indshield, T.W.M.Boileau, S.K. Clinton and J.W. Erdman Jr. 2014. Tomato phytochemicals and prostate cancer risk. International Research Conference on Food, Nutrition and Cancer. Washington, D.C.July $15-16,2014$.

Cheeke, P.R. 2005. Livestock Feeds and Feeding. 3rd ed. Upper Saddle River, New 
Jersey:Pearson Prentice Hall.

Chowdhury, S.D., S. Ahmed and M.A. Hamid. 2006. Improved feeding of Desi chicken reared in confinement. The Bangladesh Veterinarian. 23: 29-35.

Donkoh, A. 1989. Ambient temperature: A factor affecting performance and physiological response of broiler chickens. Int. J. Biometeorol. 33: 259-265.

Emshaw, Y., A. Melesse and G. Assefa. 2012. The effect of dietary inclusion of mango (Magniferaindica L.) fruit waste on feed intake, growth and feed efficiency of cobb500 broiler chickens. Ethiop. J. Agric. Sci. 22:73-83.

Fallahi, M. 1996. Tomato Alteration Industry (Tomato Paste). Barsava edition, Tehran, Iran.

Faruque, S., M.S. Islam, M.A. Afroz, and M.M. Rahman, 2013. Evaluation of the performance of native chicken and estimation of heritability for body weight. J. Bangladesh Acad. Sci .37(1):93-101.

Frederiksen, H., S.E. Rasmussen and $M$. Schroder. 2007.Dietary supplementation with an extract of lycopene rich tomatoes does not reduce atherosclerosis in Watanabe Heritable Hyperlipidemic rabbits. Br. J. Nutr. 97: 6-10.

Iyayi, E.A. 2008. Prospects and challenges of unconventional poultry feedstuffs. Nigeria Poult. Sci. J. 5:186-194.

Jafari M., R.R. Pirmohammadi and V. Bampidis. 2006. The use of dried tomato pulp in diets of laying hens. Int. J. Poult. Sci. 5:618-622.

Jouzi, H., N. Vali and J. Pourreza. 2015. The effects of tomato pulp powder supplementation on performance and some blood parameters in japanese quail (Coturnix japonica). ARPN J. Agric. Biol. Sci. 10 (3): 103-107.

Karakaya, S., S.N. El and A.A. Tas. 2001. Antioxidant activity of some foods containing phenolic compounds. Int. J. Food Sci. Nutr. 52, 501-508.

King, A. and G. Zeidler. 2004. Tomato pomace may be a good source of vitamin $\mathrm{E}$ in broiler diets. California Agric. 58:59-62.

Kenny, A.P. 1952. The determination of cholesterol by The Liebermann-burchard reaction.clinical laboratories. 52(39):611620.

Latlief, S.J. and D.Knorr. 1983. Tomato seed protein concentrates; effects of methods of recovery upon yield and compositional characteristics. J. Food Sci. 48:1583-1586.

Leke, J.R., J.S.Mandey and F.J. Nangoy. 2015. Nutriets and cholesterol of eggs affected by dried tomato meal in laying hens. Int. J. Advanced Sci. Eng. Inform. Technol. $5(3): 27-29$.

Leke, J.R., J.S. Mandey, J. Laihad. F. Ratulangi.2016. Effect of dried Tomato meal (Solanum lycopersicum) in diet on performance and egg quality of native chicken. Proceedings, symposium The $17^{\text {th }}$ Asian-Australian Association of Animal Production Societies Animal Science Congress. Fukuoaka, Japan. 22-25 August 2016. Pp 47-49.

Lira, R.C., C. Bôa-Viagem Rabello, M. do Carmo M. Marques Ludke, P.V. Ferreira, G.R. Q. Lana and S.R.V. Lana. 2010. Productive performance of broiler chickens fed tomato waste. R. Bras. Zootec. 39(5).

Mahata, M.E., Y. Mahlil, Y. Fajri,R. Aditia and R.Yose. 2014. The utilization of red dragon fruit (Hylocereus polyrhizus) peel as broiler feed. Abstract summary, International Congress and general meeting. Society for Southeast Asian Agricultural Science (ISSAAS) in Collaboration with SAEDA, Tokyo University of Agriculture and JSTA, Tokyo, Japan.

Mahata, M.E., Y. Rizal, A.D. Hermansyah and G.A. Nurhuda. 2016. Effects of boiled tomato waste utilization in the diet on serum lipid profile and egg quality of laying-hens. Int. J. Poult. Sci. 15(12): 493-496.

Mansoori, B., M. Modirsanei and M.M. Kiaei. 2008. Influence of dried tomato pomace as an alternative to wheat bran in maize or wheat based diets, on the performance of laying hens and traits of produced eggs. Iranian J. Vet. Res. 9(4):341-346.

Moundras, C., S.R. Behr, C. Remensy and C. Demigne. 1997.Fecal losses of sterols and bile acids induced by feeding rats guar gum are due to greater pool size and liver bile acid secretion. J. Nutr. 127: 1068-1076.

Nobakht, A. and A.R. Safamehr. 2007. The effect of inclusion different levels of dried tomato pomace in laying hens diets on performance and plasma and egg yolk cholesterol contents. J. Anim. Vet. Adv. 6(9):1101-1106.

Norris D, Ng'ambi J.W, Benyi K, Makgahlela M.L., Shemilis H A and E.A. Nesamvuni. 2007. Analysis of growth curves of 
indigenous male venda and naked neck chicken. South African Journal of Animal Science, 37(1):21-26.

Pond, W.G., D.C. Church and K.R. Pond. 1995. Basic Animal Nutrition and Feeding. Canada: JohnWiley and Sons, Inc.

Rahmatnejad, E., M. Bojarpour, K.H. Mirzadeh, M. Chaji and O. Ashayerzadeh. 2009. The effect of different levels of dried tomato pomace on broilers chicken hematological indices. J. Anim. Vet. Adv. 8(10):16805593.

Ravindran V. 2013. Poultry Feed Availability and Nutrition in Developing Countries: Main Ingredients Used in Poultry Feed Formulations. Poultry Development Review. Rome, Italy: F. A. O.; 2013. p. 6769.

Sahin N., K. Sahin, M. Onderici, M. Karatepe, M.O. Smithand O. Kucuk. 2006. Effects of dietary lycopene and vitamin E on egg production, antioxidant status and cholesterol levels in Japanese quail. AsianAust. J. Anim. Sci.19:224-230.

Sahin N., C. Orhan, M. Tuzco, K. Sahin and O. Kocuk. 2008. The effects of tomato powder supplementation on performance and lipid per oxidation in quail. Poult. Sci. 87:276283.

Sayed, A.N. and A.M. Abdel-azeem. 2009.
Evaluation of dried tomato pomace as feedstuff in the diets of growing rabbits. Int. J. Agro Vet. Med. Sci. 3:2009:12-18.

Scanes, C.G, G. Brant and M.E. Ensminger. Poultry Science. 4th Ed. New Jersey: Pearson Prentice Hall; 2004. p. 100-118.

Skinner, J.T., A.L. Izat and P.W. Waldroup. 1992. Effects of dietary amino acids level and durationof finisher period on performance and carcass content of broiler forty-nine days of age. Poult. Sci. 71: 1207-1214.

Squires, M.W., E.C. Naber and V.D. Toella. 1992. The effect of heat water, acid and alkali treatment of tomato cannary waste on growth, metabolizable energy value and nitrogen utilization of broiler chicks. Poult. Sci. 71: 522-529.

Steel, R.G.D. and J.A. Torrie. 1980. Principles and Procedures of Statistics. McGraw-Hill, New York.

Thompson, K.A., M.R. Marshall, C.A. Sims, C.I. Wei, S.A. Sargentand J.W. Scott, 2000. Cultivar, maturity and heat treatment on lycopene content in tomatoes. J. Food Sci. 65:791-795.

Yitbarek, M.B. 2013. Carcass characteristics of Rhode Island Red (RIR) grower chicks feed on different levels of dried tomato pomace (DTP). Int. J. Adv. Res.1(2): 17-22. 